\title{
Hubungan Pengetahuan Ibu Hamil dan Dukungan Suami dengan Kepatuhan Melaksanakan Program Perencanaan Persalinan dan Pencegahan Komplikasi (P4K) di Kota Salatiga
}

\author{
Riani Isyana Pramasanthi \\ Magister Kedokteran Keluarga Pasca Sarjana \\ Universitas Sebelas Maret
}

\begin{abstract}
Abstrak
Program Perencanaan Persalinan dan Pencegahan Komplikasi (P4K) merupakan suatu program pemerintah dalam rangka mempercepat penurunan Angka Kematian Ibu (AKI). Cakupan pelaksanaan P4K di Kota Salatiga masih di bawah target yaitu 50\% pada tahun 2013 dan 69,20\% pada tahun 2014. Dari hasil survey didapatkan 30\% ibu hamil dan pendampingnya belum memahami tentang P4K serta manfaatnya. Tujuan menganalisis hubungan antara pengetahuan dan dukungan suami ibu hamil dengan kepatuhan melaksanakan P4K di Kota Salatiga. Jenis penelitian ini adalah observasional analitik dengan pendekatan cross sectional. Populasi penelitian ini adalah ibu hamil Trimester III di Kota Salatiga sebanyak 204 orang pada bulan November 2015. Pengambilan sampel dengan Total Sampling sebanyak 204 orang. Instrumen yang digunakan adalah kuesioner. Uji statistik yang di gunakan adalah Regresi Logistik Ganda. Ada hubungan sangat signifikan antara pengetahuan ibu hamil dengan kepatuhan melaksanakan P4K ( $<<0,001)$. Ada hubungan yang sangat signifikan antara dukungan suami dengan kepatuhan melaksanakan P4K $(\mathrm{p}<0,01)$. Ada hubungan yang sangat signifikan antara pengetahuan ibu hamil dan dukungan suami dengan kepatuhan melaksanakan $\mathrm{P} 4 \mathrm{~K}(\mathrm{p}<0,01)$. Secara keseluruhan variabel pengetahuan ibu hamil dan dukungan suami memberi pengaruh terhadap kepatuhan melaksanakan P4K sebesar 64,6\%. Kesimpulannya semakin tinggi pengetahuan ibu hamil dan dukungan suami maka semakin tinggi kepatuhan melaksanakan P4K.
\end{abstract}

Kata Kunci : Pengetahuan ibu hamil, Dukungan suami, Program Perencanaan Persalinan dan Pencegahan Komplikasi (P4K).

\section{The Relationship Pregnant Woman Between Knowledge and Husband Support with Compliance Implement Program Delivery Planning and Preventions of Complications in Salatiga}

\begin{abstract}
Program Delivery Planning and Prevention of Complications (P4K) is a government program in order to accelerate the reduction in maternal mortality ratio (MMR). Scope implementation P4K in Salatiga still below the target of 50\% in 2013 and $69.20 \%$ in 2014. From the survey found 30\% of pregnant women and companions do not understand about P4K and benefits. Objective to analyze the relationship between knowledge and husband support pregnant women with compliance implement P4K in Salatiga. Methods the study was observational analytic with cross sectional approach. The study population was the third trimester pregnant women in Salatiga many as 204 people in November 2015. Total Sampling with as many as 204 people. The instrument used was a questionnaire. The statistical test used was Multiple Logistic Regression. Results and Discussion there was a significant correlation between the knowledge of pregnant women to implement compliance P4K $(p<0.001)$. There was a significant relationship between husband's support to implement compliance P4K $(p<0.01)$. There was a significant relationship between the knowledge of pregnant women and husband support with compliance implement $P 4 K(p<0.01)$. Overall knowledge variable and husband's support variable to give effect to implement compliance P4K amounted to $64.6 \%$. Conclusion where the higher the knowledge of pregnant women and her husband support the higher compliance implement P4K.
\end{abstract}

Keywords: Knowledge of pregnant woman, husbabd support, Program Delivery Planning and Prevention of Complications (P4K).

Korespondensi:

Riani Isyana Pramasanthi

Magister Kedokteran Keluarga Pasca Sarjana Universitas Sebelas Maret

Jalan Ir. Sutami 36A Kentingan Surakarta

Mobile : 08164833946

Email : riani.isyana@gmail.com 


\section{Pendahuluan}

Pembangunan nasional berkomitmen untuk mencapai tujuan pembangunan millenium di tahun 2015 yang tersusun dalam MDG's di berbagai bidang pembangunan nasional termasuk bidang kesehatan. Millenium Development Goal's (MDG's) merupakan tujuan pembangunan serta cita-cita yang disepakati secara global oleh para pemimpin dunia dalam Millenium Summit tahun 2000 yang merupakan agenda penting dalam meningkatkan kesejahteraan masyarakat. Indonesia sebagai salah satu negara berkembang ikut serta dalam agenda Millenium tersebut

Tujuan ke-5 dari MDG's merupakan komitmen Indonesia untuk meningkatkan kesehatan Ibu dengan menurunkan Angka Kematian Ibu (AKI) sebesar 3/4 nya dalam kurun waktu 1990-2015 menjadi 102 per 100.000 kelahiran hidup. AKI ini menggambarkan tentang banyaknya kematian wanita karena kehamilan, persalinan, nifas dengan jumlah kelahiran hidup dalam satu tahun per 100.000 kelahiran hidup. Kondisi Angka Kematian Ibu (AKI) di Indonesia kenyataan masih tinggi dibanding Negara tetangga seperti Malaysia dan Singapura serta menunjukkan peningkatan. Berdasarkan SDKI tahun 1992 mencapai 390/100.000 kelahiran hidup, selanjutnya angka tersebut dapat ditekan terus sampai dengan 228 pada tahun 2007 , sedangkan pada tahun 2012 mulai naik sampai dengan angka 359 per 100.000 kelahiran hidup. Untuk mencapai angka yang ditargetkan oleh Millennium Development Goal (MDGs) menjadi 102/100.000 pada tahun 2015 memerlukan kerja keras dari seluruh komponen bangsa. ${ }^{1}$

AKI di Kota Salatiga pada tahun 2011 mencapai 212,5/100.000 kelahiran hidup, kemudian mengalami penurunan menjadi $73,4 / 100.000$ kelahiran hidup pada tahun 2012, dan pada tahun 2013 mengalami peningkatan hampir empat kali lipat menjadi 275,26/100.000 kelahiran hidup namun pada tahun 2014 menurun kembali menjadi 88/100.000 KH. Sebagian besar kematian ibu di Kota Salatiga disebabkan keterlambatan pelayanan kegawatdaruratan yang dilatarbelakangi oleh keterlambatan mengenal tanda bahaya, mengambil keputusan, mencapai fasilitas kesehatan dan mendapatkan pelayanan di fasilitas kesehatan. ${ }^{2}$

Maka pada tahun 2007 pemerintah mencanangkan $\mathrm{P} 4 \mathrm{~K}$ dalam rangka menurunkan AKI akibat komplikasi kehamilan dimana semua ibu hamil dapat terpantau oleh seluruh komponen masyarakat, baik suami, keluarga dan bidan secara cepat dan tepat. Adapun tujuan dari P4K adalah meningkatnya cakupan dan mutu pelayanan kesehatan ibu hamil dan bayi baru lahir melalui peningkatan peran aktif keluarga dan masyarakat dalam merencanakan persalinan yang aman dan persiapan menghadapi komplikasi dan tanda bahaya kebidanan bagi ibu sehingga melahirkan bayi yang sehat. Komponen utama P4K yaitu perencanaan penolong persalinan, tempat persalinan, biaya persalinan, transportasike tempat pelayanan kesehatan, pendamping persalinan, perencanaan donor darah dalam persalinan dan metode kontrasepsi setelah melahirkan. Pelaksanaan program $\mathrm{P} 4 \mathrm{~K}$ dipengaruhi oleh beberapa faktor diantaranya pengetahuan, dukungan keluarga, situasi geografis dan budaya. ${ }^{3}$ Pelaksanaan P4K di Kota Salatiga masih di bawah target dimana cakupan pelaksanaan $\mathrm{P} 4 \mathrm{~K}$ pada tahun 2013 adalah $50 \%$ dan pada tahun 2014 adalah 69,20\%. Berdasarkan hasil evaluasi P4K yang telah dilaksanakan Dinas Kesehatan di Kota Salatiga, didapatkan hasil 30\% ibu hamil dan pendampingnya belum memahami tentang P4K serta manfaatnya. ${ }^{2}$

Menurut World Health Organization (WHO) bahwa kepatuhan sangat diperlukan untuk keberhasilan suatu program. Kepatuhan merupakan fenomena multidimensi yang ditentukan oleh lima dimensi yang saling terkait, yaitu faktor pasien, faktor terapi, faktor sistem kesehatan, faktor lingkungan dan keluarga serta faktor sosial ekonomi. Studi yang dilakukan Morisky et all dalam WHO (2003) menyebutkan bahwa dalam meningkatkan kepatuhan pasien dapat dilakukan intervensi utama yaitu konseling dari tenaga kesehatan dan dukungan keluarga. ${ }^{4}$ Tujuan penelitian adalah menganalisis hubungan antara pengetahuan ibu hamil dan dukungan suami dengan kepatuhan melaksanakan $\mathrm{P} 4 \mathrm{~K}$ di Kota Salatiga.

\section{Metode}

Desain penelitian ini merupakan penelitian observasional analitik dengan pendekatan cross sectional. Penelitian dilakukan di seluruh Puskesmas Kota Salatiga. Penelitian dilaksanakan mulai bulan November 2015. Populasi dalam penelitian ini adalah ibu hamil di Kota Salatiga pada bulan November 2015 sebanyak 512 orang. Subyek dalam penelitian ini adalah semua ibu hamil Trimester III di Kota Salatiga. Besar sampel dalam penulisan ini semua ibu hamil Trimester III di Kota Salatiga pada bulan November 2015 sebanyak 204 orang dengan mempertimbangkan kriteria inklusi dan kriteria eksklusi. Kriteria Inklusinya adalah semua ibu hamil Trimester III di Kota Salatiga. Sedangkan kriteria eksklusinya adalah tidak bisa baca tulis, tidak mempunyai suami, responden sakit atau meninggal. Penulis 
mempersiapkan formulir persetujuan subyek (informed consent) dan menghormati privasi dan kerahasiaan subyek penelitian. Penelitian ini sudah memperoleh persetujuan dari Komite Etik Penelitian Kesehatan RSUD dr.Moewardi / Fakultas Kedokteran Universitas Sebelas Maret. Alat ukur yang digunakan untuk mendapatkan data dalam penelitian ini adalah kuesioner berupa pertanyaan tertulis tentang karakteristik responden (meliputi usia, tingkat pendidikan, tingkat pendapatan dan paritas), pengetahuan, dukungan suami dan kepatuhan melaksanakan Program Perencanaan persalinan dan Pencegahan Komplikasi (P4K). Untuk menguji validitas kuesioner yang digunakan dalam penelitian ini perlu dilakukan uji coba kuesioner. Uji instrumen kuesioner penelitian dilaksanakan pada ibu hamil sejumlah $30 \mathrm{ibu}$ hamil dengan umur kehamilan Trimester III pada bulan Juli tahun 2015 yang memiliki karakteristik sama dengan responden dan lokasi penelitiandi Puskesmas Sidorejo Lor, Puskesmas Sidorejo Kidul dan Puskesmas Mangunsari Kota Salatiga. Uji validitas menggunakan uji korelasi product moment, sedangkan uji reliabilitas menggunakan uji statistik alpha cronbach. Analisa data menggunakan analisis univariat, bivariat menggunakan chi-square dan multivariat dengan regresi logistik.

\section{Hasil}

Data Umum Penelitian; Data umum yang berupa karakteristik ibu hamil Trimester III di kota Salatiga dapat dilihat pada tabel 1 . Data Khusus Penelitian; Data khusus penelitian yang merupakan variabel Pengetahuan Ibu Hamil, Dukungan Suami dan kepatuhan melaksanakan P4K dapat dilihat pada tabel 2.

Tabel 1 Hasil Analisis Deskriptif Karakteristik Ibu Hamil Trimester III di Wilayah Kota Salatiga

\begin{tabular}{cccc}
\hline Variabel & Kategori & Jumlah & \% \\
\hline Usia Ibu Hamil & Risiko Tinggi & 29 & 14,2 \\
& Non Risiko Tinggi & 175 & 85,8 \\
Tingkat Pendidikan & dasar & 79 & 38,7 \\
& Tinggi & 125 & 61,3 \\
\multirow{2}{*}{ Tingkat Pendapatan } & 10 & 4,9 \\
& <Kriteria Pendapatan Keluarga & & \\
& Miskin (Rp. 600.000) & 194 & 95,1 \\
& $\geq$ Kriteria Pendapatan Keluarga & & \\
Paritas & Miskin ( Rp.600.000) & 158 & 77,5 \\
& $\leq 1$ & 46 & 22,5 \\
\hline
\end{tabular}

Tabel 2 Hasil Analisis Deskriptif Pengetahuan Ibu Hamil, Dukungan Suami Ibu Hamil dan kepatuhan melaksanakan P4K di Kota Salatiga

\begin{tabular}{cccc}
\hline Variabel & Kategori & Jumlah & \% \\
\hline Pengetahuan Ibu Hamil & Kurang (skor $<13$ ) & 78 & 38,2 \\
& Baik (skor $\geq 13$ ) & 126 & 61,8 \\
Dukungan Suami & Kurang (skor $<32$ ) & 94 & 46,1 \\
& Baik (skor $\geq 32)$ & 110 & 53,9 \\
Kepatuhan P4K & Tidak patuh (skor $<7$ ) & 50 & 50,0 \\
& Patuh (skor=7) & 50 & 50,0 \\
\hline
\end{tabular}


Analisa Bivariat; Hasil analisis bivariat hubungan antara karakteristik ibu hamil dengan kepatuhan melaksanakan P4K ditunjukkan pada tabel 3.

Analisis Multivariat; Analisis multivariat dilakukan untuk mengetahui variabel mana di antara variabel bebas yang berpengaruh secara bersama-sama terhadap kepatuhan ibu hamil dalam melaksanakan P4K dan diantara variabel bebas yang berpengaruh secara bersama-sama tersebut, variabel mana yang paling dominan berpengaruh terhadap kepatuhan ibu hamil dalam melaksanakan P4K di Wilayah Kota Salatiga. Analisis multivariat dalam penulisan ini menggunakan Regresi Logistik Ganda karena variabel bebas menggunakan skala ordinal dan variabel terikat menggunakan skala nominal.

\section{Pembahasan}

Hubungan Usia Ibu Hamil dengan Kepatuhan dalam Melaksanakan P4K; Hasil analisis hubungan antara usia ibu hamil dengan kepatuhan dalam melaksanakan P4K dengan menggunakan uji chi square diperoleh nilai P adalah 1,000. Hal ini berarti bahwa tidak ada hubungan antara usia ibu hamil dengan kepatuhan dalam melaksanakan P4K di Wilayah Kota Salatiga. Hal ini mungkin terjadi karena baik ibu hamil risti dan non risti mematuhi anjuran bidan untuk melaksanakan P4K. Hasil penulisan ini sejalan dengan penulisan yang dilakukan Mohdari et al (2014) yaitu tidak terdapat hubungan antara umur dengan kepatuhan melakukan kunjungan Ante Natal Care $(A N C){ }^{5}$

Hubungan Pendidikan Ibu Hamil dengan Kepatuhan dalam Melaksanakan P4K; Hasil analisis hubungan antara tingkat pendidikan ibu hamil dengan kepatuhan dalam melaksanakan P4K dengan menggunakan uji chi square diperoleh nilai $\mathrm{P}$ adalah 0,021 . Hal ini berarti bahwa ada hubungan antara tingkat pendidikan ibu hamil dengan kepatuhan dalam melaksanakan P4K di Wilayah Kota Salatiga. Pemahaman ibu atau pengetahuan ibu terhadap perencanaan persalinan sangat dipengaruhi oleh tingkat pendidikan ibu. Latar belakang pendidikan ibu yang rendah menyulitkan berlangsungnya suatu penyuluhan kesehatan terhadap ibu karena kurang menyadari pentingnya informasi-informasi tentang pentingnya Program Perencanaan Persalinan dan Pencegahan Komplikasi (P4K). Hasil penulisan ini relevan dengan penulisan Umaroh (2012) yang menyimpulkan bahwa ada hubungan antara tingkat pendidikan ibu hamil multigravida dengan kunjungan ANC. ${ }^{6}$ Diketahui bahwa pada kunjungan ANC dilakukan perencanaan persalinan untuk mencegah komplikasi. Demikian pula dengan penulisan yang dilakukan Windyastuti et al (2014) yang menyimpulkan bahwa ada hubungan yang bermakna antara pendidikan dengan rencana pemilihan penolong persalinan. ${ }^{7}$

\section{Tabel 3 Hubungan antara Karakteristik Ibu Hamil dengan Kepatuhan Ibu Hamil dalam Melaksanakan P4K di Wilayah Kota Salatiga}

\begin{tabular}{|c|c|c|c|c|c|c|c|c|}
\hline \multirow{3}{*}{ Variabel } & \multirow{3}{*}{ Kategori } & \multicolumn{4}{|c|}{$\begin{array}{c}\text { Kepatuhan Melaksanakan } \\
\text { P4K } \\
\end{array}$} & \multirow{3}{*}{$\mathrm{X} 2$} & \multirow{3}{*}{ 95\% CI } & \multirow{3}{*}{$\begin{array}{r}\mathbf{P} \\
\%\end{array}$} \\
\hline & & \multicolumn{2}{|c|}{ Patuh } & \multicolumn{2}{|c|}{ Tidak Patuh } & & & \\
\hline & & $\sum$ & $\%$ & $\sum$ & $\%$ & & & \\
\hline \multirow[t]{2}{*}{ Usia Ibu Hamil } & Non Risti & 87 & 49,7 & 88 & 50,3 & 0,000 & $0,420-2,026$ & 1,000 \\
\hline & Risti & 15 & 51,7 & 14 & 48,3 & & & \\
\hline \multirow[t]{2}{*}{ Pendidikan } & Tinggi & 71 & 56,8 & 54 & 43,2 & 5,289 & $1,147-3,613$ & $0,021^{*}$ \\
\hline & Dasar & 31 & 39,2 & 48 & 60,8 & & & \\
\hline \multirow[t]{2}{*}{ Pendapatan } & $\geq 600.000$ & 96 & 49,5 & 98 & 50,5 & 0,105 & $0,179-2,387$ & 0,746 \\
\hline & $<600.000$ & 6 & 60,0 & 4 & 40,0 & & & \\
\hline \multirow[t]{2}{*}{ Paritas } & $\leq 1$ org & 86 & 54,1 & 73 & 45,9 & 4,106 & $1,076-4,238$ & $0,043^{*}$ \\
\hline & $>1$ org & 16 & 35,6 & 29 & 64,4 & & & \\
\hline \multirow[t]{2}{*}{ Pengetahuan } & Baik & 77 & 61,1 & 49 & 38,9 & 15,132 & $1,837-6,042$ & $0,000^{*}$ \\
\hline & Kurang & 25 & 32,1 & 53 & 67,9 & & & \\
\hline \multirow[t]{2}{*}{ Dukungan Suami } & Baik & 71 & 64,5 & 39 & 35,5 & 18,960 & $2,070-6,614$ & $0,000^{*}$ \\
\hline & Kurang & 31 & 33,0 & 63 & 67,0 & & & \\
\hline
\end{tabular}


Hubungan antara Pendapatan dengan Kepatuhan melaksanakan P4K; Analisis hubungan antara pendapatan keluarga ibu hamil trimester III dengan kepatuhan dalam melaksanakan P4K menggunakan uji chi square diperoleh nilai $\mathrm{P}$ adalah 0,746 . Hal ini berarti bahwa tidak ada hubungan antara pendapatan keluarga ibu hamil trimester III dengan kepatuhan dalam melaksanakan P4K di Wilayah Kota Salatiga. Hasil penulisan Rusnawati (2012) didapatkan bahwa pendapatan merupakan salah satu faktor yang berhubungan dengan pemilihan tempat persalinan. ${ }^{8}$ Penenelitian lain yang dilakukan Ayisi et al (2006) di Western Kenya, menyatakan bahwa $80 \%$ persalinan terjadi di luar fasilitas kesehatan karena rendahnya status sosial ekonomi. ${ }^{9}$ Sedangkan pada penulisan ini didapatkan hasil bahwa tidak ada hubungan antara pendapatan keluarga ibu hamil dengan kepatuhan dalam melaksanakan P4K. Hal ini dimungkinkan karena dalam P4K belum secara langsung membutuhkan biaya sehingga tidak berhubungan secara langsung dengan pendapatan. Selain itu dengan adanya program Jaminan Kesehatan Nasional (JKN) - Penerima Bantuan Iuran (PBI) yang menyediakan biaya gratis untuk semua persalinan dan komplikasi kehamilan dan persalinan bagi keluarga miskin maka kendala biaya yang selama ini sering terjadi dan merupakan masalah di masyarakat secara perlahan mulai dapat diatasi.

Hubungan antara Paritas dengan Kepatuhan melaksanakan P4K; Jika dilihat dari hasil uji statistik menggunakan uji chi square diperoleh nilai $\mathrm{P}$ adalah 0,043 . Hal ini berarti bahwa ada hubungan antara paritas dengan kepatuhan dalam melaksanakan P4Kdi Wilayah Kota Salatiga. Hasil penulisan ini tidak relevan dengan penulisan Restiyanti et al (2013) yang menyatakan tidak ada hubungan antara paritas dengan perencanaan persalinan. ${ }^{10}$ Begitu pula dengan penulisan Amirullah (2013) yang mengemukakan bahwa tidak adanya hubungan paritas dengan perencanaan persalinan ${ }^{11}$ dan Agarwal et al (2010) dari India yang menyatakan bahwa paritas tidak memiliki hubungan dengan perencanaan persalinan. ${ }^{12}$

Hubungan antara Pengetahuan Ibu Hamil tentang P4K dengan Kepatuhan Melaksanakan P4K; Jika dilihat dari hasil uji statistik menggunakan uji chi square diperoleh nilai $P$ adalah 0,014. Hal ini berarti bahwa ada hubungan yang signifikan antara pengetahuan ibu hamil tentang $\mathrm{P} 4 \mathrm{~K}$ dengan kepatuhan dalam melaksanakan P4K di wilayah Kota Salatiga. Temuan penulisan ini sesuai dengan tinjauan teoritik, yaitu pengetahuan ibu hamil menentukan kepatuhan dalam melaksanakan
Program Perencanaan Persalinan dan Pencegahan Komplikasi (P4K). Pengetahuan (knowledge) merupakan hasil "tahu" dan ini terjadi setelah orang melakukan penginderaan terhadap suatu objek tertentu. Penginderaan terjadi melalui panca indera manusia. Sebagian besar pengetahuan manusia diperoleh melalui mata dan telinga. ${ }^{13}$ Pengetahuan ibu hamil tentang $\mathrm{P} 4 \mathrm{~K}$ adalah segala sesuatu yang diketahui oleh perempuan yang sedang hamil tentang perencanaan persalinan untuk mengoptimalisasi kesehatan mental fisik ibu hamil sehingga mampu menghadapi persalinan, kala nifas, persiapan memberi ASI dan kembalinya kesehatan reproduksi secara wajar. Hasil penulisan ini relevan dengan penulisan Pertiwi (2013) yang menyimpulkan bahwa ada hubungan antara pengetahuan dan sikap ibu hamil dengan $\mathrm{P} 4 \mathrm{~K} .{ }^{14}$ Penulisan yang dilakukan Rizki et al (2013) juga menyimpulkan bahwa ada hubungan yang signifikan antara pengetahuan ibu tentang $\mathrm{P} 4 \mathrm{~K}$ dengan pemilihan tempat persalinan dimana pemilihan tempat persalinan merupakan salah satu komponen dari P4K..$^{15}$ Demikian pula menurut Martadila (2013) yang menyatakan bahwa ada hubungan bermakna antara pengetahuan dan sikap dengan penerapan $\mathrm{P} 4 \mathrm{~K} .{ }^{16} \mathrm{Ibu}$ hamil yang berpengetahuan rendah, kurang menyikapi sehingga sebagian besar tidak mengetahui pentingnya penerapan P4K. Penulisan Kabakyenga et al (2011) juga menyimpulkan terdapat hubungan signifikan antara pengetahuan dengan persiapan kehamilan. Semakin meningkatnya pengetahuan ibu hamil akan diikuti peningkatan kepatuhan melaksanakan P4K, sebaliknya semakin rendah pengetahuan ibu hamil maka kepatuhannya juga semakin rendah. Hal ini menuntut para tenaga kesehatan untuk memberikan informasi yang lengkap tentang pentingnya P4K. ${ }^{17}$

Hubungan antara Dukungan Suami dengan Kepatuhan Melaksanakan P4K; Jika dilihat dari hasil uji statistik menggunakan uji chi square diperoleh nilai $\mathrm{P}$ adalah 0,000 . Hal ini berarti bahwa ada hubungan sangat signifikan antara dukungan suami ibu hamil trimester III terhadap P4K dengan kepatuhan dalam melaksanakan P4K di Wilayah Kota Salatiga. Hasil penulisan ini sesuai dengan tinjauan teoritik, yaitu dukungan suami ibu hamil menentukan kepatuhan dalam melaksanakan P4K. Hasil penulisan yang menunjukkan bahwa ada hubungan dukungan suami dengan kepatuhan dalam melaksanakan $\mathrm{P} 4 \mathrm{~K}$ sejalan dengan hasil penulisan yang dilakukan oleh Ambarwati et al (2013), dalam hasil penulisannya disebutkan bahwa ada hubungan antara dukungan suami dengan kepatuhan kunjungan Antenatal Care (ANC). ${ }^{18}$ Penyebab dari tingginya dukungan suami secara langsung 
karena bidan desa memberikan penyuluhan tentang pentingnya dukungan suami pada ibu hamil untuk berperan aktif dalam kesehatan yaitu membekali suami dengan informasi yang benar dan mengikut sertakan dalam setiap upaya peningkatan kesehatan, suami merupakan partner untuk mencapai kesehatan yang lebih baik. Hasil penulisan lain yang juga sejalan dengan hasilpenulisan ini adalah yang didapatkan oleh Hayu (2014), yang menunjukan bahwa ada hubungan yang signifikan antara dukungan suami dengan kepatuhan ibu hamil dalam memeriksakan kehamilan. ${ }^{19}$ Penulisan yang dilakukan oleh Kakaire et al (2012) juga menyatakan bahwa jika ibu hamil dan pasangannya diberikan penyuluhan akan memberikan dampak yang lebih baik dalamkepatuhan memeriksakan kehamilannya dibandingkan jika hanya ibu hamil saja yang diberikan penyuluhan. ${ }^{20}$

Hubungan antara Pengetahuan dan Dukungan Suami dengan Kepatuhan Melaksanakan P4K; Sinergis dengan hipotesis pertama dan kedua mengenai hubungan pengetahuandan dukungan suami dengan kepatuhan melaksanakan P4K, didapatkan bahwa terdapat hubungan yang signifikan antara pengetahuan dan dukungan suami dengan kepatuhan melaksanakan P4K. Dukungan suami merupakan variabel yang paling dominan berpengaruh terhadap kepatuhan ibu hamil dalam melaksanakan $\mathrm{P} 4 \mathrm{~K}$.

Dari hasil penulisan ini menginformasikan bahwa betapa pentingnya pemberian informasi tentang P4K baik kepada ibu hamil maupun suami karena dukungan suami dan pengetahuan ibu hamil merupakan faktor yang paling dominan terhadap kepatuhan melaksanakan $\mathrm{P} 4 \mathrm{~K}$. Jika ibu hamil patuh melaksanakan P4K maka ibu hamil dapat lebih siap dalam menghadapi proses persalianannya. Dengan demikian akan terwujud tujuan pemerintah untuk menurunkan angka kematian ibu dan bayi.

Adapun keterbatasan dan kelemahan penelitian, yang ada antara lain dikarenakan keterbatasan penulis, tidak semua faktor yang mempengaruhi kepatuhan melaksanakan P4K diteliti. Faktor yang perlu diteliti lebih lanjut antara lain adalah peranan petugas kesehatan, budaya dan faktor geografis; Penelitian ini menggunakan desain cross sectional (potong lintang). Pada desain cross sectional semua variabel diukur pada saat yang sama sehingga tidak dapat memastikan besar hubungan antara pengetahuan dan dukungan suami sebagai sebab serta kepatuhan P4K sebagai akibat. Dengan demikian pada penelitian selanjutnya perlu dipertimbangkan desain penelitian yang lebih baik yaitu menggunakan desain Cohort.

Berdasarkan hasil penulisan yang telah dikemukakan, dapat disimpulkan ada hubungan yang antara pengetahuan ibu hamil dengan kepatuhan melaksanakan $\mathrm{P} 4 \mathrm{~K}$; ada hubungan yang antara dukungan suami dengan kepatuhan melaksanakan $\mathrm{P} 4 \mathrm{~K}$; ada hubungan yang antara pengetahuan ibu hamil dan dukungan suami dengan kepatuhan melaksanakan P4K.

\section{Daftar Pustaka}

1. BKKBN Prop.Jateng. 2014. Mengurangi Resiko Kematian Ibu Melahirkan. http:// www.jateng.bkkbn.go.id/infoprogram/ Documents/artikel-AKI.docx.Diakses tanggal 18 Mei 2015.

2. Dinas Kesehatan Kota Salatiga. 2014.Profil Kesehatan Kota SalatigaTahun2014. Salatiga : Dinas Kesehatan Kota Salatiga

3. Departemen Kesehatan RI. 2009. Pedoman Praktis Program Program Perencanaan Persalinan dan Pencegahan Komplikasi (P4K) dengan stiker. Jakarta: Departeman Kesehatan RI.

4. WHO. 2003. Adherence to Long-term Therapies Evidence for action.

h t t p : / / a p s . w ho.int / i r is bitstream/10665/42682/1/9241545992.pdf. Diakses 6 Oktober 2015.

5. Mohdari, Sinambela, Dewi., Saropah, Maria. 2014. Hubungan antara Umur dan Pendidikan Ibu Primigravida dengan kepatuhan melakukan kunjungan ANC di Puskesmas Pekauman. Banjarmasin: STIKES Sari Mulia.

6. Umaroh, M. 2012. Hubungan Tingkat Pendidikan Ibu Hamil Multigravida dengan Kunjungan Antenatal Care (ANC) di BPM Ny.Tutik S. Sidoarjo: Akbid Mitra Sehat.

7. Windyastuti,E., Sari, Prista, S.,Lukman., Mamat., Yamin, Ahmad. 2014. Faktor-faktor yang Berhungan dengan Rencana Pemilihan Pertolongan Persalinan pada Ibu Hamildi Kelurahan Margawati Wilayah Kerja Puskesmas Pasundan Kabupaten Garut. Surakarta: STIKES Kusuma Husada.

8. Rusnawati. 2012. Faktor-faktor yang berhubungan dengan Pemilihan Tempat Persalinan di Wilayah Kerja Puskesmas Negara Kec. Daha Utara Kab. Hulu Sungai Selatan Prop. Kalimantan Selatan. Depok: Universitas Indonesia.

9. Ayisi,J.G.Eijk,A.M.,Bless,H.M.,Odhiambo ,F.,Blokland,I.,Rosen,D.,Adazu,K.,Slutskr ,L and Lindblade,K. 2006. Use of antenatal services and delivery care among women in rural western Kenya: a community based survey.http://www.ncbi.nlm.nih.gov/pmc/ articles/PMC1459114. Diakses tanggal 13 
Januari 2015.

10. Restiyanti, Ansariadi, Wahiduddin. 2013. Determinan Perencanaan Persalinan pada Ibu Bersalin di Daerah Pedesaan Kabupaten Toraja Utara. Makassar: Universitas Hasanudin.

11. Amirullah. 2012 Hubungan Karakteristik Sosial Ekonomi dan Paritas dengan Perencanaan Persalinan Ibu Hamil di Kelurahan Layang Kecamatan Bontoala Kota Makassar. Makassar:Fakultas Kesehatan Masyarakat Universitas Hasanuddin.

12. Agarwal,S., Sethi,V., Srivastava, K., Prabhat K. and Baqui, A. 2010. Birth Preparedness and Complication Readiness among Slum Women in Indore City, India. http://www.ncbi. nlm.nih.gov/pmc/articles/PMC2965330/. Diakses tanggal 13 Januari 2016.

13. Notoatmodjo S. 2005. Promosi kesehatan dan Ilmu Perilaku. Jakarta. Rineka Cipta.

14. Pertiwi, D. 2013. Hubungan Pengetahuan dengan Sikap Ibu Hamil tentang Program Perencanaan Persalinan dan Pencegahan Komplikasi (P4K) Sebagai Upaya Pencegahan Komplikasi Kehamilan di Kelurahan Kutambaru Kabupaten Langkat. Medan: Universitas Sumatra Utara.

15. Rizki,A., Kristiyanti,R., Indriyana, D. 2013 Hubungan yang Antara Pengetahuan Ibu tentang Program Perencanaan Persalinan dan Pencegahan Komplikasi (P4K) Dengan Pemilihan Tempat Persalinan di Wilayah Kerja Puskesmas Kajen I
Kabupaten Pekalongan.Pekalongan:STIKES Muhammadiyah Pekajangan.

16. Martadila,A. 2013. Hubungan Pengetahuan dan Sikap Ibu Hamil Terhadap Penerapan P4K ( Program Perencanaan Persalinan dan Pencegahan Komplikasi ) di Aur Birugo Tigo Baleh Bukittinggi. Padang: STIKES Prima Nusantara.

17. Kabakyenga,J.K., Östergren, P, Turyakira, E and Pettersson, K. 2011. Knowledge of obstetric danger signs and birth preparedness practices among women in rural Uganda. http://link.springer.com/ article/10.1186\%2F1742-4755-8-33\#page-1. Diakses 29 November 2015.

18. Ambarwati,B ,Kusuma,D.T, Mahfirah, M.E. 2013. Hubungan Dukungan Suami dengan Kepatuhan Kunjungan Antenatal Care (anc) pada Ibu Hamil Trimester III di Rumah Bersalin Pemerintah Kota Malang. Malang: STIKES Kendedes

19. Hayu,M. 2014. Hubungan Dukungan Suami Terhadap Tingkat Kepatuhan Pemeriksaan Kehamilan Primigravida di Puskesmas Simo Mulyo Surabaya. Surabaya: STIKES Hangtuah

20. Kakaire, O., Kayel, D and Osinde, M. 2011. Male Involvement In Birth Preparedness and Complication Readiness for Emergency Obstetric Referrals In Rural Uganda. http:// www.ncbi.nlm.nih.gov/pubmed/21548976. Diakses 28 November 2015. 